\title{
Evaluation of embryotoxic and embryostatic effects of the aqueous extract of Rhizophora mangle and tannic acid on eggs and larvae of Aedes aegypti
}

\author{
AGEU A. RODRIGUES NETO ${ }^{1}$, PLÍNIO P. GOMES JÚNIOR ${ }^{2}$, MAURICIO C. SILVA ${ }^{1}$, CLÁUdiA \\ S.A. LIMA ${ }^{3}$, RICARDO YARA ${ }^{3}$, EMÍLIA B. GUIMARÃES ${ }^{1}$, EDUARDA S. DE SANTANA ${ }^{1}$, \\ LUZIA A. DA SILVA ${ }^{1}$, EDUARDO J.R.V. DE LIRA ${ }^{1}$ and JEYMESSON R.C. VIEIRA ${ }^{1}$ Moraes Rego, 1235, Cidade Universitária, 50760-420 Recife, PE, Brazil
${ }^{2}$ Laboratório de Biologia da Unidade de Serra Talhada, Universidade Federal Rural de Pernambuco, Av. Gregório Ferraz Nogueira, 56909-535 Serra Talhada, PE, Brazil
${ }^{3}$ Departamento de Biofísica, Universidade Federal de Pernambuco, Av. Prof. Moraes \\ ${ }^{1}$ Departamento de Histologia e Embriologia, Universidade Federal de Pernambuco, Av. Prof. \\ Rego, 1235, Cidade Universitária, 50760-420 Recife, PE, Brazil
}

Manuscript received on May 4, 2017; accepted for publication on June 14, 2017

\begin{abstract}
Rhizophora mangle is an abundant plant in mangroves and tannic acid is a polyphenol produced by the secondary metabolism of plants. The aim of the study was to evaluate the embryotoxic and embriostatic effects of the aqueous extract of $R$. mangle and synthetic tannic acid on eggs and larvae of Aedes aegypti. A. aegypti eggs were exposed in duplicate at concentrations of $250,500,750$ and $1000 \mu \mathrm{g} / \mathrm{mL}$ of extract and tannic acid for a period of 14 days. Mineral water was used as a negative control. The eggs were observed and counted in a stereomicroscope $(1.2 \mathrm{x})$. In all extract concentrations there was stimulation in hatching in relation to the control, but only in concentration of $750 \mathrm{mg} / \mathrm{mL}$ it was statistically significant. In tannic acid $(250 \mu \mathrm{g} / \mathrm{ml})$ there was significant stimulus in hatching, but in 500,750 and $1000 \mu \mathrm{g} / \mathrm{mL}$ there was significant inhibition. All concentrations of aqueous extract and tannic acid on larvae showed embryotoxic and embryostatic effects when compared to the control. The aqueous extract of $R$. mangle showed effect on hatching of $A$. aegypti eggs and synthetic tannic acid showed embryotoxic and embryostatic effects. On larvae, both the aqueous extract as tannic acid showed embryotoxic and embryostatic effects.
\end{abstract}

Key words: Aedes aegypti, embryostatic, embryotoxic, Rhizophora mangle, tannic acid.

\section{INTRODUCTION}

Aedes aegypti is the mosquito that transmits dengue, ZIKA fever, chikungunya fever and yellow fever. It is a serious public health problem given

Correspondence to: Jeymesson Raphael Cardoso Vieira

E-mail: jeymesson@gmail.com

* Contribution to the centenary of the Brazilian Academy of Sciences. the complications that cause thouse arboviruses. This insect has acquired great adaptability to human dwellings, accompanying people on their migrations across continents. Aedes aegypti reproduces in clean water reservoirs, strictly in the home environment, distancing itself just meters from human habitations; therefore it is not usually found in Brazilian rural areas, where houses appear 
isolated (Donalísio and Freitas 2014, Vasconcelos 2015).

The female mosquitoes are responsible for the spread of disease since the oviposition process is dependent on blood repasts. Egg maturation or oogenesis starts after the blood repast. In Aedes aegypti complete ovariolar maturation is necessarily related to digestion of one or more blood repasts. If there is no complete intake of blood, the development of oocytes will not pass the first stage (Carron et al. 2007).

One of the strategies to combat arboviruses is the elimination of the vector through insecticides. As a result of the continued use of these products came the resistant populations. Moreover, undesirable effects of such insecticides as remaining for long periods of time cause environmental impacts. These facts stimulated research on natural products. Several studies point to compounds of plant origin with larvicidal activity for use in vector control (Park et al. 2002, Silva et al. 2003, Rajeswary and Govindarajan 2014).

Plants have been evaluated as sources of natural insecticides against $A$. aegypti, and larvicidal bioassays have been conducted using third (L3) and fourth (L4) instars or comparing the effect of plant extracts on larval development of L1-L4. Various studies have addressed the possibility of using the embryo culture technique as an assay for embryotoxic potential of xenobiotic compounds. The electron microscopy of $A$. aegypti larvae transmission treated with aqueous extracts of Derris urucu and Indigofera suffruticosa showed histological changes in the intestine, and larval mortality was associated with damage to peritrophic matrix (Gusmão et al. 2002, Vieira et al. 2012). The peritrophic matrix of insects consists of proteins, glycoproteins, proteoglycans, and chitin (Nation 2016) and its integrity is important in the digestive process, as well as to protect against invasion by microorganisms and parasites (Lievin-Le and Servin et al. 2006). Plants have been evaluated as natural insecticides sources and bioassays have been conducted using larvae in third (L3) and fourth (L4) stages or comparing plant extracts effect on larval development L1-L4 (Murugan et al. 2007).

Rhizophora mangle $\mathrm{L}$ is the most frequently plant found in the Brazilian mangrove (Chapman 1970, Silva et al. 2005). It belongs to Rhizophoraceae family and is known by the popular name mangrove or red mangrove. It is a plant whose leaves, stem, roots and fruits have varied applications in folk medicine (Coelho-Ferreira 2009) being used for treatment against gastric ulcers (De-Faria et al. 2012) as an antibacterial (Melchor et al. 2001), antioxidant (Sánchez et al.2006), anti-inflammatory (Marrero et al. 2006), antidiarrheal (Wendel et al. 2013) and also in healing skin wounds (Fernandez et al. 2002).

Leaf and stem extracts of $R$. mangle L. exhibited insecticidal activity against Cylas formicarius performed by triterpenoids that act synergistically with each other and with other compounds that potentiate this effect, indicating its potential as a new source of insecticidal products of natural origin, which are better tolerated and of quicker degradation in the environment than those of synthetic origin (Williams 1999).

Tannins are among the major polyphenolic compounds of $R$. mangle L., including both polymeric and hydrolyzables tannins (Berenguer et al. 2006). Tannic acid is a hydrolysable tannin, produced by the secondary metabolism of plants and belongs to the large category of phenolic acids. It is found in many foods such as grapes, lentils, chocolate, red wine, beer, coffee, black tea and green tea. (Apud Genaro-Mattos 2009).

Studies have shown that tannic acid has embryotoxic activity on Culicidae larvae, but have not reported effects on eggs (David et al. 2000).

The need for research aimed at controlling the Aedes aegypti vector, arboviruses-causing, leads to research of compounds of synthetic and natural 
origin in order to provide data for development of less toxic, more efficient and low-cost products in the fight against mosquitoes. Studies have addressed the possibility of using the embryo culture technique as a test for the embryotoxic potential of xenobiotics compounds (Murugan et al. 2007). Therefore, this study was developed in order to prove that the aqueous extract of $R$. mangle leaves and synthetic tannic acid have embryotoxic and embryostatic effects on eggs and larvae of Aedes aegypti.

\section{MATERIALS AND METHODS}

\section{STUDY DESIGN}

This study was developed by the Translational and Innovation Therapeutics Laboratory Research team of the Department of Histology and Embryology of the Federal University of Pernambuco (UFPE) Biosciences Center in partnership with the Laboratory of Biology of the Academic Unit of Serra Talhada of the Federal Rural University Pernambuco. This is an experimental study (in vitro) on embryotoxic and embryostatico effects of aqueous extract of $R$. mangle leaves and synthetic tannic acid in eggs and larvae of $A$. aegypti.

\section{VEGETABLE MATERIAL}

Rhizophora mangle leaves were collected in the Vila Velha district, Itamaraca, State of Pernambuco, Brazil (latitude $7^{\circ} 40^{\prime}$ south and longitude $34^{\circ} 50^{\prime}$ west) with the permission of Pernambuco Company Control of Environmental Pollution (Companhia Pernambucana de Controle da Poluição Ambiental) and Water Resources Management (Administração de Recursos Hídricos) under CA DRFB $\mathrm{N}^{\mathrm{O}}$ $120 / 2014$. The plant was identified by biologist Marlene Barbosa, curator of UFP Herbarium of the Biosciences Center (CCB) of the Federal University of Pernambuco. A voucher specimen of the plant material was deposited in properly listed Herbarium collection and cataloged under number
UFP. 69,655 .

AQUEOUS EXTRACT PREPARATION OF $R$. mangle AND TANNIC ACID

$R$. mangle leaves $(500 \mathrm{~g})$ were weighed, crushed and subjected to extraction by infusion with distilled water $\left(80^{\circ} \mathrm{C}\right)$. After lyophilization, the material was stored at $20^{\circ} \mathrm{C}$. The dry residue (100mg) of aqueous extract was homogenized in $100 \mathrm{ml}$ distilled water and diluted in water in concentrations of $250,500,750$, and $1000 \mu \mathrm{g} / \mathrm{m}$. Tannic acid was purchased commercially (Merck, Germany) and stored at room temperature and diluted in the same concentrations as the extract.

EGG COLLECTION

Egg collection of natural populations of Aedes aegypti was performed by ovitraps installed in volunteer homes. The ovitraps were made with Polyethylene terephthalate bottles (PRBs) and painted black to attract mosquitoes. Within the same bottles $0.5 \mathrm{mg}$ of biological larvicide (Bti) were placed to prevent from becoming a breeding ground. Cardboard rolls were used to substrate oviposition pieces.

\section{HATCHING}

Before starting the experiments, the eggs were counted and washed to ensure no effect on the part of Bti. Then 10 eggs were placed in a disposable cup. For the experiment with larvae, the eggs were put for hatching in a $1 \%$ hay-water solution then divided in groups of 10 larvae in L1 stage.

\section{EMBRYOTOXIC AND EMBRYOSTATIC TEST}

The experiments were carried out over 14 days. In the study, Aedes aegypti larvae and eggs were placed in $180 \mathrm{ml}$ disposable plastic cups containing the aqueous extract of Rizophora mangle and tannic acid solution. Each extract was used at four different concentrations: $250 \mu 1 / \mathrm{ml}, 500 \mu 1 / \mathrm{ml}$, 
$750 \mu 1 / \mathrm{ml}$ and $1000 \mu 1 / \mathrm{ml}$, and a control group. All treatments were performed in duplicate. The cups were identified by date, extract concentration and if there were larvae or eggs. Feeding was administered in all treatments whenever necessary to prevent death by starvation, $\mathrm{CEDAN}{ }^{\circledR}$ for fish being used to feed. Daily observations every 24 hours were carried out with the aid of Motik ${ }^{\circledR}$ microscopestereoscope in the microscopy laboratory UFRPEAcademic Unit of Serra Talhada. The hatchings and seedlings were duly noted and then transferred to an Excel ${ }^{\circledR}$ spreadsheet. The laboratory temperature was maintained at around $27^{\circ} \mathrm{C}$.

\section{STATISTICAL ANALYSIS}

Data was analyzed descriptively by absolute and percentage frequencies and was analyzed inferentially using the Pearson's Chi-squared test or Fisher's exact test when the condition was not verified for using the chi-square test, or the Verisimilitude Reason test when it was not possible to obtain the results by Fisher's exact test. The margin of error used in the statistical tests was $5 \%$. Data was entered in an Excel spreadsheet and the program used for the preparation of statistical calculations was the SPSS version 21.

\section{RESULTS}

In all concentrations of aqueous extract of R. mangle, there was stimulus in hatching in relation to the control, but only in the $750 \mathrm{mg} / \mathrm{mL}$ concentration was there statistically significant stimulus (Table I).

At the $250 \mu \mathrm{g} / \mathrm{mL}$ concentration of the synthetic tannic acid there was a significant stimulus in hatching, but at 500,750 and $1000 \mu \mathrm{g} / \mathrm{mL}$ there was a significant inhibition (Table II).

Figure 1 shows the frequency of hatching of $A$. aegypti eggs in 14 days relating the aqueous extract of $R$. mangle with synthetic tannic acid. The $500 \mu \mathrm{g} / \mathrm{mL}$ concentration of tannic acid showed a greater embryostatic effect considering that there were no hatching eggs.

Regarding the larvae, all concentrations of aqueous extract and tannic acid showed statistically significant embryotoxic and embryostatic effects when compared to the control during the 14 days of the experiment (Tables III and IV).

\section{DISCUSSION}

The results of this study showed that aqueous extract of $R$. mangle showed a stimulating effect on hatching eggs and embryotoxic and embryostatic effects on $A$. aegypti larvae.

Studies reporting effects on the development of A. Aegypti with Rhiophora mangle were not found in literature, but plants from mangrove showed effects on eggs and larvae (Kabaru and Gichia 2001, Santana et al. 2013a). Extracts of the stem and Rhizophora mucronata pulp showed high toxicity against $A$. Aegypti larvae with values $\mathrm{LC}_{50} 157.4$ ppm for stem and $168.3 \mathrm{ppm}$ for pulpa (Kabaru and Gichia 2001). According to Santana et al. (2013b), the aqueous extract of pneumatophore Avicenia shaueriana showed significant inhibitory effect on hatching $A$. aegypti eggs in the concentrations of 250,500 and $\mu \mathrm{g} / \mathrm{mL}$.

The percentage of hatching was $22.5 \%$, $35 \%$ and $22.5 \%$ respectively in the $1000 \mu \mathrm{g} / \mathrm{mL}$ concentration, there was no significant difference compared to the negative control. Study with aqueous extract of $C$. erectus leaves revealed that there was hatching in $55 \%$ for the negative control, and at concentrations of 250, 500, 750 and 1000 $\mu \mathrm{g} / \mathrm{mL}$ after five days of exposure. The hatching percentage was $5 \%, 7.5 \%, 0 \%$ and $5 \%$, respectively (Santana et al. 2013a).

The fact that it was observed in this study increase of hatching in the presence of aqueous extract of $R$. mangle, leads to a new perspective in relation to the factors that stimulate $A$. aegypti eggs to hatch. It is suggested that the stimulus caused by the aqueous extract of $R$. mangle is 
TABLE I

Assessment of embryotoxic and embryostatic effects of aqueous extract of $R$. mangle in eggs of A. aegypti over 14 days

\begin{tabular}{|c|c|c|c|c|c|c|}
\hline \multicolumn{7}{|c|}{ Group } \\
\hline Result & Control $^{(\mathrm{A})}$ & $250 \mathrm{~g} / \mathrm{mL}^{(\mathrm{A})}$ & $500 \mathrm{~g} / \mathrm{mL}^{(\mathrm{AB})}$ & $750 \mathrm{~g} / \mathrm{mL}^{(\mathrm{B})}$ & $1000 \mathrm{~g} / \mathrm{mL}^{(\mathrm{A})}$ & TOTAL \\
\hline Hatched & 6 & 11 & 12 & 10 & 7 & 46 \\
\hline Hatched and died & 1 & - & 2 & 7 & 1 & 11 \\
\hline Non-hached & 13 & 9 & 6 & 3 & 12 & 43 \\
\hline TOTAL & 20 & 20 & 20 & 20 & 20 & 100 \\
\hline
\end{tabular}

$\mathrm{p}=0.003$ by Fisher's exact test.

If between parentheses, they are distinct significant difference between the groups is proven.

TABLE II

Evaluation of embryotoxic and embryostatic effects of synthetic tannic acid in $A$. aegypti eggs over 14 days

\begin{tabular}{|c|c|c|c|c|c|c|}
\hline \multirow[b]{2}{*}{ Result } & \multicolumn{6}{|c|}{ Group } \\
\hline & Control $^{(\mathrm{A})}$ & $250 \mathrm{~g} / \mathrm{mL}^{(B)}$ & $500 \mathrm{~g} / \mathrm{mL}^{(\mathrm{C})}$ & $750 \mathrm{~g} / \mathrm{mL}^{(\mathrm{C})}$ & $1000 \mathrm{~g} / \mathrm{mL}^{(\mathrm{C})}$ & TOTAL \\
\hline Hatched & 6 & 15 & - & 1 & 1 & 23 \\
\hline Hatched and died & 1 & 3 & - & 1 & 1 & 6 \\
\hline Non-hatched & 13 & 2 & 20 & 18 & 18 & 71 \\
\hline TOTAL & 20 & 20 & 20 & 20 & 20 & 100 \\
\hline
\end{tabular}

$\mathrm{p}=0.001$ by Fisher's exact test.

If between parentheses, they are distinct significant difference between the groups is proven.

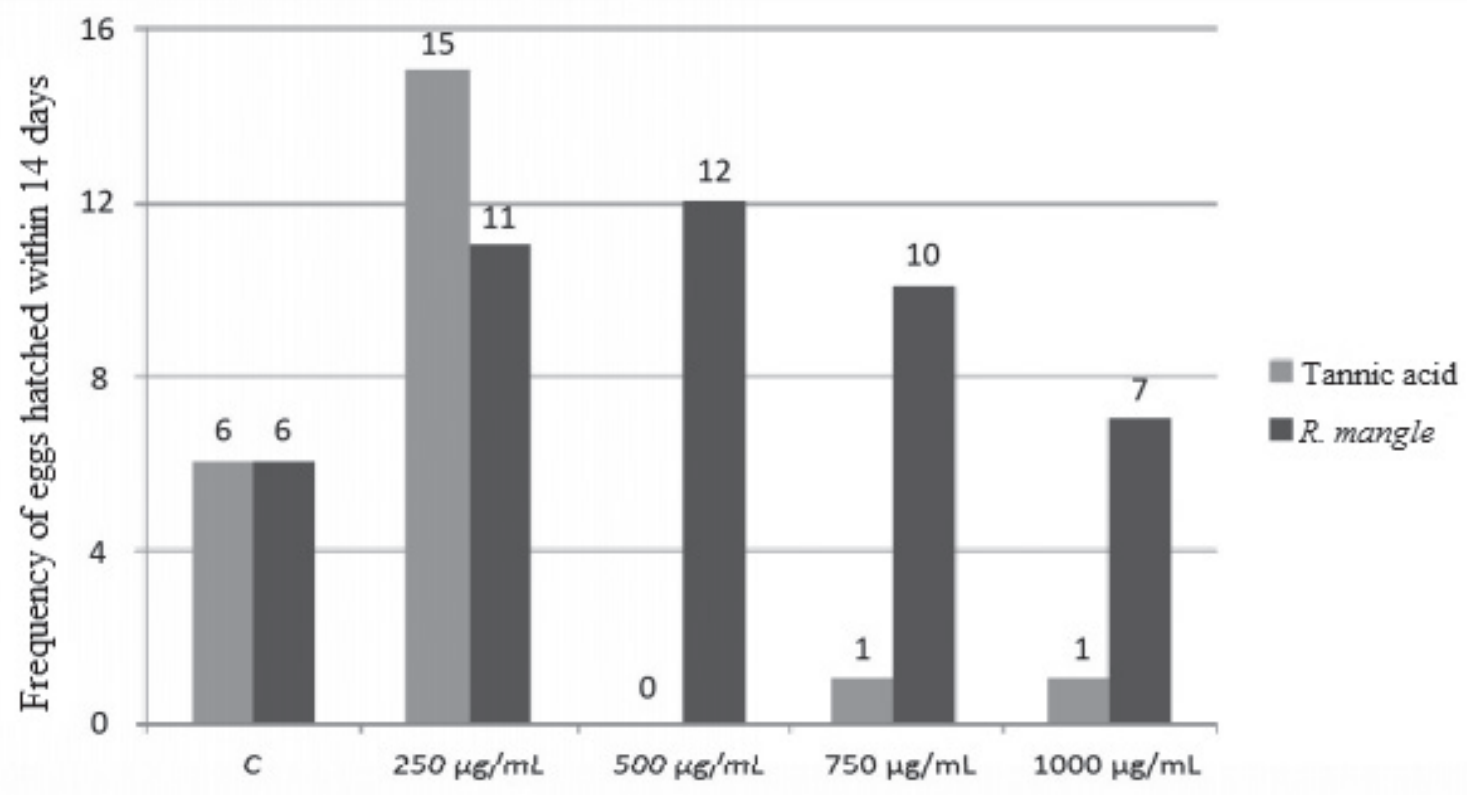

Figure 1 - Frequency of egg hatchability during 14 days on aqueous extract of R. mangle and tannic acid. 
TABLE III

Evaluation of embryotoxic and embryostatic effects of aqueous extract of $R$. mangle in $A$. aegypti larvae over 14 days

\begin{tabular}{|c|c|c|c|c|c|c|}
\hline \multicolumn{7}{|c|}{ Group } \\
\hline Result & Control $^{(A)}$ & $250 \mathrm{~g} / \mathrm{mL}^{(B)}$ & $500 \mathrm{~g} / \mathrm{mL}^{(\mathrm{BC})}$ & $750 \mathrm{~g} / \mathrm{mL}^{(\mathrm{BC})}$ & $1000 \mathrm{~g} / \mathrm{mL}^{(\mathrm{C})}$ & TOTAL \\
\hline L1 & - & - & - & - & 2 & 2 \\
\hline L2 & - & - & - & 1 & 2 & 3 \\
\hline L3 & - & - & 1 & - & 2 & 3 \\
\hline L4 & 5 & 4 & 6 & 2 & 2 & 19 \\
\hline Pupae & 15 & 6 & 3 & 1 & - & 25 \\
\hline Dead & - & 10 & 10 & 16 & 12 & 48 \\
\hline TOTAL & 20 & 20 & 20 & 20 & 20 & 100 \\
\hline
\end{tabular}

$\mathrm{p}<0.001$ by Verisimilitude Reason test with comparisons between groups pairs using Fisher's exact test.

If between parentheses, they are distinct significant difference between the groups is proven.

TABLE IV

Evaluation of embryotoxic and embryostatic effects of of synthetic tannic acid in $A$. aegypti larvae over 14 days

\begin{tabular}{|c|c|c|c|c|c|c|}
\hline \multicolumn{7}{|c|}{ Group } \\
\hline Result & Control $^{(\mathbf{A})}$ & $250 \mathrm{~g} / \mathrm{mL}^{(B)}$ & $500 \mathrm{~g} / \mathrm{mL}^{(\mathrm{B})}$ & $750 \mathrm{~g} / \mathrm{mL}^{(\mathrm{C})}$ & $1000 \mathrm{~g} / \mathrm{mL}^{(\mathrm{C})}$ & TOTAL \\
\hline $\mathrm{L} 1$ & - & - & - & - & 1 & 1 \\
\hline L2 & - & - & - & 1 & 2 & 3 \\
\hline L3 & - & - & - & - & 1 & 1 \\
\hline L4 & 5 & 1 & 3 & - & - & 9 \\
\hline Pupae & 15 & 6 & 5 & - & - & 26 \\
\hline Dead & - & 13 & 12 & 19 & 16 & 60 \\
\hline TOTAL & 20 & 20 & 20 & 20 & 20 & 100 \\
\hline
\end{tabular}

$<0.001$ by Verisimilitude Reason test with comparisons between groups pairs using Fisher's exact test.

If between parentheses, they are distinct significant difference between the groups is proven.

due to the antioxidant effects of polyphenols and its free radicals with their chelating properties (Haslam 1996). It has been shown that chlorogenic acid, which is present in the aqueous extract of $R$. mangle, has an antioxidant effect as high as DLtocopherol (Gjullin et al. 1939) studied mosquito eggs (Ae. Vexans (Meigen) and Ae. Aldrichi Dyar and Knab [=Ae.sticticus (Meigen)]) in plant fermented infusion, observed a significant increase in hatching. The authors attributed this effect to the presence of amino acids, proteins and phosphate salts present in the plant.

In literature, there are quotations showing inhibition activity hatching of $A$. aegypti eggs from plant extracts. According to Vieira et al. (2012),
Indigofera suffruticosa, common plant of rural and arid regions (agreste and sertão) in Pernambuco, showed embryotoxic activity in relation to hatching $A$. aegypti eggs as well as repellent action in oviposition activity.

In this study, synthetic tannic acid at a concentration of $250 \mu \mathrm{g} / \mathrm{mL}$, stimulated the hatching of $A$. aegypti eggs. In other concentrations tested, there were embryotoxic and embryostatic effects on both eggs as larvae.

In nature, the presence of tannic acid in low concentrations seems to provide chemical and nutritional conditions suitable for larval development similarly to that found in this study (Yadav 1997). Conversely at higher concentrations 
tannins exhibit high toxicity.

Studies have shown that the major toxic effects caused by tannins in the mesenteron cells of larvae in the third instar of $A$. aegypti were: high cytoplasmic vacuolation, abscence of cytoplasmic limits, apical vesicle formation with the release of cytoplasmic contents of the cells, increased intercellular space and detached cells from the basement membrane. These results are similar to those histopathological processes reported in insects, in response to a variety of biological toxic substances (Abed et al. 2007, Arruda et al. 2003, Barreto et al. 2006, Delphine et al. 1999, Gusmão et al. 2002, Rey et al. 1999).

Histopathological studies in which tannic acid is used against Diptera larvae demonstrated that changes first reached the anterior region of the midgut, progressing to the median and posterior regions (Rey et al. 1999). Molan et al. (2002) showed that tannin inhibited the development of eggs and Trichostrongylus colubriformis larvae in concentrations from 200 to $500 \mu \mathrm{g} / \mathrm{mL}$. This result indicates that tannins have an inhibitory effect even in higher organisms in the evolutionary scale.

New insecticides of herbal origin discovered through ethnopharmacological studies have shown interesting results. Purification of tannins from Rhizophora mangle is underway, and further investigations may improve our understanding of possible development of natural products in Aedes aegypti control.

\section{ACKNOWLEDGMENTS}

We would like to thank the Coordenação de Aperfeiçoamento de Pessoal de Nível Superior (CAPES) for the financial support and the biologist Marlene Barbosa for the identification of the plant.

\section{REFERENCES}

ABED RA, CAVASIN GM, SILVA HHG AND SILVA IG. 2007. Alterações morfohistológicas em larvas de Aedes aegypti (Linnaeus, 1762) (Diptera, Culicidae) causadas pela atividade larvicida do óleo-resina da planta medicinal Copaifera reticulata Ducke Leguminosae). Rev Patol Trop 36: 87-95.

ARRUDA W, OLIVEIRA GMC AND SILVA IG. 2003. Toxicidade do extrato etanólico de Magonia pubescens sobre larvas de Aedes aegypti. Rev Soc Bras Med Trop 36: $17-25$.

BARRETO CF, CAVASIN GM, SILVA HHG AND SILVA IG. 2006. Estudos das alterações morfohistológicas em larvas de Aedes aegypti (Diptera, Culicidae) submetidas ao extrato bruto etanólico de Sapindus saponaria Lin (Sapindaceae). Rev Patol Trop 35: 37-57.

BERENGUER B, SANCHEZ LM, QUILEZ A, LOPEZBARREIRO M, HARO O, GALVEZ J AND MARTIN MJ. 2006. Protective and antioxidant effects of Rhizophora mangle L. against NSAID-induced gastric ulcers. J Ethnopharmacol 103: 194-200.

CARRON A, ANGELARD C, BOULLET A AND HERVÉ JP. 2007. Christophers' stage durations and effect of interrupted blood meal in the mosquito Aedes caspius (Diptera: Culicidae). Parasite 14: 225-229.

CHAPMAN VJ. 1970. Mangrove phytosociology. Trop Ecol 11: $1-19$.

COELHO-FERREIRA M. 2009. Medicinal knowledge and plant utilization in an Amazonian coastal community of Marudá, Pará State (Brazil). J Ethnopharmacol 26: 159175.

DAVID JP, REY D, PAUTOU MP AND MEYRAN JC. 2000. Differential toxicity of leaf litter to dipterian larvae of mosquito developmental sites. J Invertebr Pathol 75: 9-18.

DE-FARIA FM ET AL. 2012. Mechanisms of action underlying the gastric antiulcer activity of the Rhizophora mangle L. J Ethnopharmacol 139: 234-243.

DELPHINE R, PAUTOU MP AND MEYRAN JC. 1999. Histopathological effects of tannic acid on the midgut epithelium of some aquatic Diptera larvae. J Invertebr Pathol 73: 173-181.

DONALISIO MR AND FREITAS ARR. 2014. Chikungunya in Brazil: an emerging challenge. Rev Bras Epidemiol 18: 283-285.

FERNANDEZ O, CAPDEVILA JZ, DALLA G AND MELCHOR G. 2002. Efficacy of Rhizophora mangle aqueous bark extract in the healing of open surgical wounds. Fitoterapia 73: 564-568.

GENARO-MATTOS TC. 2009. Mecanismos de ação antioxidante dos ácidos caféico e tânico em sistemas contendo íons ferro. Brasília: Instituto de Química, Universidade de Brasília.

GJULLIN CM, YATES WW AND STAGE HH. 1939. The effect of certain chemicals on the hatching of mosquito eggs. Science 89: 539-540.

GUSMÃO DS, PÁSCOA V, MATHIAS L, VIEIRA IJC, 
BRAZ-FILHO R AND LEMOS FJA. 2002. Derris (Lonchocarpus) urucu (Leguminosae) Extract Modifies the Peritrophic Matrix Struture of Aedes aegypti (Diptera: Culicidae). Mem Inst Oswaldo Cruz 97: 371-375.

HASLAM E. 1996. Natural Polyphenols (Vegetable Tannins) as Drugs: Possible Modes of Action. J Nat Prod 56(2): 205-215

KABARU JM AND L GICHIA. 2001. Insecticidal activity of extracts derived from different parts of the mangrove tree Rhizophora mucronata (Rhizophoraceae) Lam. against the arthropods. Afr J Sci Technol 2: 44-49.

LIEVIN-LE MV AND SERVIN AL. 2006. The front line of enteric host defense against unwelcome intrusion of harmful microorganisms: mucins, antimicrobial peptides, and microbiota. Clin Microbiol Rev 19: 315-337.

MARRERO E, SÁNCHEZ J, ARMAS E, ESCOBAR A, MELCHOR G, ABAD MJ, BERMEJO P, VILLAR AM, MEGÍAS J AND ALCARAZ MJ. 2006. COX-2 and SPLA2 inhibitory activity of aqueous extract and polyphenols of Rhizophora mangle (red mangrove). Fitoterapia 77: 313315.

MELCHOR G, ARMENTEROS M, FERNANDEZ O, LINARES E AND FRAGAS I. 2001. Antibacterial activity of Rhizophora mangle Bark. Fitoterapia 72: 689-691.

MOLAN AL, WAGHORN GC AND MCNABB WC. 2002. Effect of condensed tannins on egg hatching and larval development of Trichostrongylus colubriformis in vitro. Vet Rec 19: 65-69.

MURUGAN K, MURUGAN P AND NOORTHEEN A. 2007. Larvicidal and repellent potential of Albizzia amara Boivin and Ocimum basilicum Linn against dengue vector, Aedes aegypti (insecta: Diptera: Culicidae). Bioresour Technol 98: 198-201.

NATION JL. 2016. Insect Physiology and biochemistry, no. 13. Gainesville: CRC press, $46 \mathrm{p}$.

PARK IK, LEE SG, SHIN SC, PARK JD AND AHN YJ. 2002. Larvicidal activity of isobutylamides identified in Piper nigrumfruits against three mosquito species. J Agric Food Chem 50: 1866-1870.

RAJESWARY M AND GOVINDARAJAN M. 2014. Adulticidal properties of Pithecellobium dulce (Roxb.) Benth.(Family: Fabaceae) against dengue vector, Aedes aegypt (Linn.) (Diptera: Culicidade). Asian Pac J Trop Dis
4: 4449-4452.

REY D, CUANY A, PAUTOU MP AND MEYRAN JC. 1999. Differencial sensitivity of mosquito taxa to vegetable tannins. J Chem Ecol 25: 537-548.

SÁNCHEZ J, MELCHOR G, MARTÍNEZ G, ESCOBAR A AND FAURE R. 2006. Antioxidant activity of Rhizophora mangle bark. Fitoterapia 77: 141-143.

SANTANA MAN ET AL. 2013a. Embriotoxicidade de extrato aquoso de Conocarpus erectus sobre Aedes aegypti. Resumos Expandidos do CONICBIO / II CONABIO / VI SIMCBIO (v.2), Universidade Católica de Pernambuco, Recife, Brasil.

SANTANA MAN ET AL. 2013b. Efeito do extrato aquoso de Avicenia schaueriana sobre Aedes aegypti. Resumos Expandidos do I CONICBIO / II CONABIO / VI SIMCBIO (v.2), Universidade Católica de Pernambuco, Recife, Brasil.

SILVA IG ET AL. 2003. Efeito larvicida e toxicológico do extrato bruto etanólico da casca do caule de Magonia pubescens sobre Aedes aegypti (Diptera, Culicidae) em criadouros artificiais. Rev Patol Trop 32: 73-86.

SILVA MAB, BERNINI E AND CARMO TMS. 2005. Características estruturais de bosques de mangue do estuário do rio São Mateus, ES, Brasil. Acta Bot Bras 19: 465-471.

VASCONCELOS PFDC. 2015. Doença pelo vírus Zika: um novo problema emergente nas Américas? Rev Panamazonica Saúde 6: 9-10.

VIEIRA JRCV et al. 2012. Oviposition and embryotoxicity of Indigofera suffruticosa on early development of Aedes aegypti (Dptera: Culicidae). eCAM 2012: 5.

WENDEL GH, TEVES MR, PAREDES JD, SANCHEZ PLM AND PELZER LE. 2013. Evaluation of the Antidiarrheal Activity of Rhizophora mangle L. (Rhizophoraceae). Lat Am J Pharm 32: 128-131.

WILLIAMS LAD. 1999. Rhizophora mangle (Rhizophoraceae) triterpenoids with insecticidal activity. Naturwissenschaften 86: 450-452.

YADAV TD. 1997. Safe storage of pulse crops. In: Asthana AN, Ali M, editors. Recent Advances of Pulses Research. Indian Society of Pulses Research and Development, Kanpur. Indian Society of Pulses Research and Development, p. 649-662. 